\title{
Calcareous foraminifera from the Ordovician of Baltoscandia
}

\author{
R. E. L. SCHALLREUTER \\ Department of Geology, University of Hamburg, W. Germany
}

\begin{abstract}
Ordovician erratic boulders from northern Germany have yielded uniserial calcareous foraminifers which were previously unknown from the Baltoscandian Ordovician. They represent at least two new species which are provisionally placed in the genus Saccamminopsis Sollas, 1921
\end{abstract}

\section{INTRODUCTION}

Ordovician calcareous foraminifers are seldom recorded. According to Eisenack (1954) there are no indications of their presence in the Baltic Ordovician. Bykova (1956) described three species, referred by her to the Lagenidae, from the Middle Ordovician of Latvia: Cochleatina plavinensis Bykova, 1956, Lagena cylindrica Smith and $L$ aranea Bykova, 1956. C. plavinensis is a bryozoan not a foraminifer, and probably belongs to Corynotrypa Bassler (Loeblich \& Tappan, 1964, p. C786). I have previously (1977) described the queried calcareous foraminifer Glomovertella ? iecta from a Baltic Middle Ordovician erratic boulder of northern Germany. This form is a member of the questionable order of foraminifera Reitlingerellida Vologdin, 1958. The specimens of $G$.? iecta were preserved complete; previously, reitlingerellids were known only from thin sections. Another calcareous foraminifer is possibly that represented by the problematical microfossil, Microancientia anularis Schallreuter, 1980. Apart from these questionable forms, true calcareous foraminifers also occur rarely in the author's material of Ordovician erratic boulders from northern Germany; not only unichambered (by preservation) but also multichambered uniserial species which were hitherto unknown from the Ordovician (Eisenack, 1971, p. 355). The Nodosaria? (Ehrenberg, 1858a, b) from the Lower Ordovician is probably an inorganic, globular concretionary mass of glauconite as are Dexiospira and Spirocerium (Loeblich \& Tappan, 1964, p. C786).

\section{ORDOVICIAN CALCAREOUS FORAMINIFERA}

The oldest known Ordovician calcareous foraminifer is, according to Loeblich \& Tappan (1964, p. C135), Saccamminopsis Sollas, 1921 (family Moravamminidae, Parathuramminacea). The type-species, Saccammina carteri Brady, 1871, is from the Carboniferous and according to Cummings (1952, p. 223) is synonymous with another Carboniferous species, Nodosaria fusulinaformis M'Coy, 1849. Ordovician forms from the Girvan area of Scotland recorded by various authors are listed by Cummings (1952, p. 225) as Saccamminopsis cf. fusulinaformis. This is the oldest occurrence of foraminifera in Britain (Murray, 1981, p. 13). The Silurian specimens from the basal Wenlock Woolhope Limestone of Wych, Malvern in the Welsh Borderlands (Brady, 1888), are considered by Cummings (1952, p. 225) to be identical "with either Ordovician or Carboniferous examples of Saccamminopsis". The taxonomic position of the Ordovician specimens described by Bykova cannot be ascertained on the basis of the published figures.

The material described herein comes from cherty limestones and cherts found as erratic boulders in northern Germany and was etched out by Wetzel's method (Schallreuter, 1982). In the rocks with Saccamminopsis? teschenhagensis, the calcareous microfossils were preserved in calcareous form so that it was possible to dissolve the siliceous matrix using hydrofluoric acid (HF). The material of Saccamminopsis? syltensis is secondarily silicified; this is true also of Microancientia anularis Schallreuter, 1980 from the boulders of Sylt (those from Gotland are still calcareous as shown by EDAX analysis).

\section{SYSTEMATIC DESCRIPTIONS}

Suborder Fusulinina Wedekind, 1937

Superfamily Parathuramminacea Bykova, 1955

Family Moravamminidae Pokorný, 1951

Subfamily Earlandiinae Cummings, 1955

Genus Saccamminopsis Sollas, 1921

Saccamminopsis ? syltensis $\mathrm{sp}$. nov.

(Pl. 1, figs. 2, 3, 6 (? figs. 1, 4, 5); Table 1)

Derivation of name. From the type locality.

Diagnosis. Length of chamber (including neck) $c$. $1.5 \mathrm{~mm}$ (holotype $1.54 \mathrm{~mm}$ long, $0.69 \mathrm{~mm}$ broad). Chamber more or less pear-shaped, neck of chamber very 
long; about as long or longer than rest of chamber, and considerably narrower than greatest width of chamber.

Holotype. A single chamber, Geologisch-Paläontologisches Institut und Museum, University of Hamburg (GPIMH) no. 2565 - Pl. 1, figs. 3a, b.

Material. 6 large (typical) single chambers (nos. 2564, $2565,2568,2580,2581,2584)$ and more than 30 small single chambers (nos. 2563, 2566, 2567, 2582, 2885 $2590=S$. ? sp. cf. syltensis) from 6 erratic boulders from the type locality (boulders Sy1, Sy2, Sy56, Sy83, Sy 97 , Sy 115).

Locality and horizon. Near Braderup, Isle of Sylt (North Sea), Schleswig-Holstein, Germany. Erratic boulder (no. Sy 1) from the Upper Kaolinsand (Lower Pleistocene). Origin: presumably the region of the Hall Banks, N. or N.E. of the Isle of Gotland (Baltic Sea). Öjlemyrflint (Braderup type), Porkuni-Stage $\left(F_{2}\right)$ or possibly Pirgu-Stage $\left(\mathrm{F}_{1} \mathrm{c}\right)$ of Estonia, Uppermost Harjuan (Upper Ordovician) (Schallreuter, 1979).

Dimensions. See Table 1.

Remarks. Most of the specimens clearly show two apertures, as in the type-species (Brady, 1871, p. 183) but no connected chambers have been observed. Specimen no. 2582 (Pl. 2, fig. 4), which comes from the same boulder as no. 2566 ( $\mathrm{Pl}$. 1, fig. 4), is possibly an intermediate form between a single chamber and a row of chambers.

The type-species of Saccamminopsis, Saccammina carteri Brady, 1871, is much larger (average long diameter of the chambers $=$ about $3.2 \mathrm{~mm}$ ); its chambers are, as a rule, fusiform, sometimes subspherical or pyriform, and the neck is much shorter than in S.? syltensis (Brady, 1871, pl. XII, fig. 2; Loeblich \& Tappan, 1964,p. fig. 232.1) The test of $S$. carteri was originally regarded as agglutinated but restudy by Sollas showed that it was originally calcareous; secondary silicification and infilling had caused the labyrinthic appearance (Loeblich \& Tappan, 1964. p. C319).

$S$. fusulinaformis sensu Cummings, 1952 from the Ordovician is the same size ( $1.6 \mathrm{~mm}$, range: $1.3-1.7 \mathrm{~mm})$ but cannot be compared with $S$.? syltensis because of the lack of plates or figures.

S.? syltensis was found in three boulders (Table 1). In all samples large forms are accompanied by similar but smaller forms which are here referred to as $S . ? \mathrm{sp}$. cf. syltensis (Pl. 1, figs. 1, 4,5), and which may represent the A form of $S . ?$ syltensis. The length of the small forms varies from about $0.35-0.45 \mathrm{~mm}$. The Middle Ordovician Lagena cylindrica sensu Bykova, 1956 is of about the same size $(0.48 \mathrm{~mm})$ and similar to slender variants of $S$. ? cf. syltensis (compare Pl. 1. fig. 5 with Bykova, 1956, pl. II, fig. 1).

Table 1. Dimensions of Saccaminopsis? syltensis sp. nov.

\begin{tabular}{|c|c|c|c|c|c|c|c|c|c|}
\hline $\begin{array}{l}\text { Spec } \\
\text { GPIMH } \\
\text { no. }\end{array}$ & $\begin{array}{l}\text { men } \\
\text { from } \\
\text { boulder }\end{array}$ & $\mathrm{L}$ & $\mathbf{L}_{\mathrm{n}}$ & W & $W_{n}$ & $\mathrm{~L}: \mathrm{W}$ & $L_{n}:\left(L-L_{n}\right)$ & $W: W_{n}$ & $\begin{array}{l}\text { Pl. } 1 \text {, } \\
\text { fig. }\end{array}$ \\
\hline $2565 *$ & Sy 1 & 1.54 & 0.90 & 0.69 & 0.12 & 2.23 & 0.59 & 0.18 & $3 a-b$ \\
\hline 2580 & Sy 115 & 1.51 & 0.61 & 0.52 & 0.14 & 2.89 & 0.40 & 0.22 & \\
\hline 2581 & Sy 56 & 1.49 & 0.81 & 0.52 & 0.16 & 2.87 & 0.54 & 0.32 & \\
\hline 2564 & Sy 115 & 1.42 & 0.73 & 0.44 & 0.17 & 3.22 & 0.52 & 0.39 & 2 \\
\hline 2568 & Sy 115 & $(>1.05)$ & $(>0.39)$ & 0.50 & 0.10 & $?$ & $?$ & 0.20 & 6 \\
\hline
\end{tabular}

$\mathrm{L}=$ length, $\mathrm{W}=$ width, $\mathrm{n}=$ neck of chamber; dimensions in $\mathrm{mm}$.

holotype

\section{Explanation of Plate 1}

Figs. 1, 4, 5. Saccamminopsis? sp. cf. syltensis (: A form of S.? syltensis ?): fig. 1, stereo-pair, GPIMH 2563 $(\times 150)$; fig. 4, GPIMH 2566 (× 175); fig. 5, GPIMH 2567 (× 175). Öjlemyrflint erratic boulder no. Sy 1 (figs. 1 , 5) and Sy115 (fig. 4) of the Upper Kaolinsand (Lower Pleistocene) near Braderup, Isle of Sylt (North Sea).

Figs. 2, 3, 6. Saccamminopsis? syltensis sp. nov.: fig. 2, stereo-pair, GPIMH 2564 ( $\times 55$ ); fig. 3, stereo-pairs, holotype GPIMH $2565(3 \mathrm{a} \times 55,3 \mathrm{~b} \times 75)$; fig. 6, GPIMH $2568(\times 65)$. Boulders Sy 1 (fig. 3$)$ and Sy $115(f i g s$. $2,6)$. 

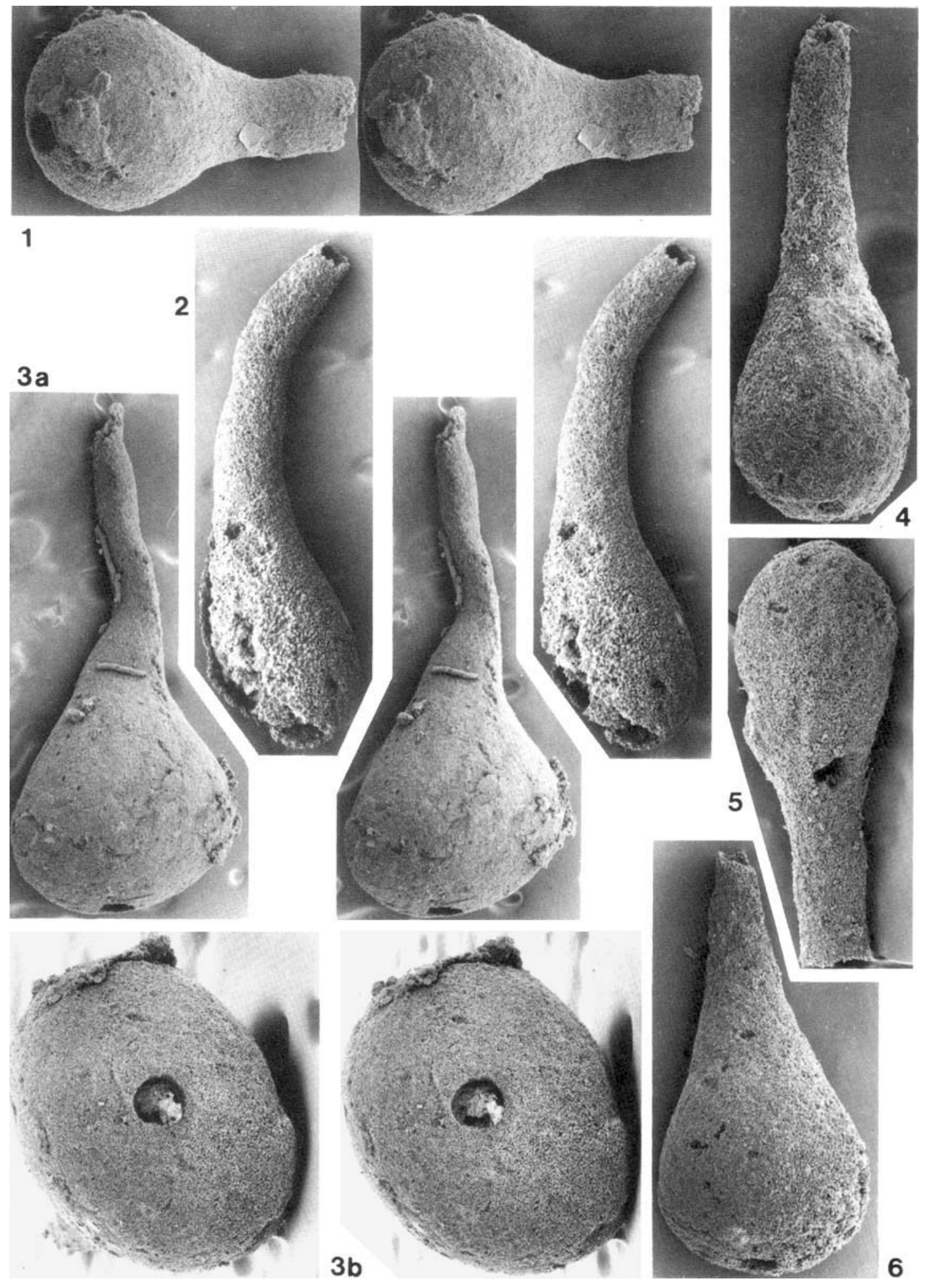
Saccamminopsis? teschenhagensis sp. nov. (Pl. 2, figs. 1, 2 (? figs. 3, 5), Table 2)

Derivation of name. From the type locality.

Diagnosis. Length of holotype ( 4 chambers, first chambers missing) $2.42 \mathrm{~mm}$. Chambers becoming longer in oral direction and wider with nearly constant length: width ratio (mean 1.4). Chambers egg-shaped with blunt end up or elliptical; neck of chambers only short and relatively broad $(2 / 5-3 / 5$ of the greatest width of chamber). Holotype with a broad round aperture at the top of the final chamber (width about $1 / 4$ of the width of the chamber).

Holotype. A 4-chambered specimen, GPIMH no. 2570 Pl. 2, fig. 1.

Material. 10 specimens from boulder 14B2 (nos. GPIMH 2570 - 2579) and 1 specimen from boulder $1 \mathrm{~B} 10$ (no. 2569). The holotype is the most complete specimen. The other specimens are fragmentary rows comprising 1-4 more or less complete chambers.

Locality and horizon. Teschenhagen near Stralsund, Pomerania, Germany. Erratic boulder (no. 14B2). Origin: presumably from the bottom of the Baltic Sea, N. of the Isle of Gotland and S. of Åland-Is. Backsteinkalk of $14 \mathrm{~B} 2$-type. Idavere-Stage $\left(\mathrm{C}_{3}\right)$ or Johvi-Stage $\left(D_{1}\right)$ of Estonia = Lower Upper Viruan (Middle Ordovician) (Schallreuter, 1970:65).

Dimensions. See Table 2.
Remarks. The specimen from boulder 1B 10 (Pl. 2, fig. 2) exhibits no broad aperture at the end of the final chamber, only a fine perforation; at the other (broken) end the test is open to full width. In one specimen with two chambers (GPIMH 2573) the upper chamber shows (besides the normal neck) a short second neck-like projection with a broken end indicating bifurcation similar to that in the specimen of $S$. carteri figured by Brady (1871, pl. II, fig. 2, right; right; Loeblich \& Tappan, 1964, fig. 232.1, $3^{\text {rd }}$ chain from left).

Some of the smaller specimens from boulder 14 B 2 are distinguished from the typical specimen by having more slender chambers and broader necks between the chambers (Pl. 2, fig. 3) The length of the chamber varies between 0.21 and $0.35 \mathrm{~mm}$ and is not very different between chambers of a row ( 2 or 3 ); the length: width ratio varies between 1.53 and 2.56 . It is at present hard to say whether they represent more juvenile parts of rows or whether they belong to another species; they are therefore referred to here as $S$.? sp. cf. teschenhagensis.

Saccamminopsis carteri is much larger. The chambers of a row are all of about the same size (hence the questionable generic assignment of the new species) and the necks between the chambers are very thin (Brady, 1871, pl. XII, fig. 2; Loeblich \& Tappan, 1964, fig. 232.1).

Table 2. Dimensions of Saccaminopsis? teschenhagensis sp. nov.

\begin{tabular}{ccccccccccc}
\hline \multicolumn{3}{c}{$\begin{array}{c}\text { GPIMH 2570 (holotype) } \\
\text { (Plate 2, fig. 1) }\end{array}$} & & \multicolumn{5}{c}{$\begin{array}{c}\text { GPIMH 2569 } \\
\text { (Plate 2, fig. 2) }\end{array}$} \\
\hline $\mathrm{L}$ & $\mathrm{W}$ & $\mathrm{W}_{\mathrm{n}}$ & $\mathrm{L}: \mathrm{W}$ & $\mathrm{W}: \mathrm{W}_{\mathrm{n}}$ & $\mathrm{L}$ & $\mathrm{W}$ & $\mathrm{W}_{\mathrm{n}}$ & $\mathrm{L}: \mathrm{W}$ & $\mathrm{W}: \mathrm{W}_{\mathrm{n}}$ \\
\hline 0.72 & 0.53 & 0.24 & 1.36 & 0.45 & & & & & \\
0.65 & 0.50 & 0.19 & 1.30 & 0.38 & 0.65 & 0.46 & 0.27 & 1.41 & 0.59 \\
0.58 & 0.41 & 0.15 & 1.41 & 0.37 & 0.58 & 0.45 & 0.27 & 1.29 & 0.60 \\
0.46 & 0.29 & 0.12 & 1.59 & 0.41 & 0.46 & 0.36 & 0.23 & 1.28 & 0.64 \\
\hline
\end{tabular}

$\mathrm{L}=$ length, $\mathrm{W}=$ width, $\mathrm{n}=$ neck of chamber; dimensions in $\mathrm{mm}$.

\section{Explanation of Plate 2}

Figs. 1, 2. Saccaminopsis? teschenhagensis sp. nov.: fig. 1, stereo-pair, holotype, GPIMH $2570(\times 45)$, Backsteinkalk erratic boulder no. 14B 2 from Teschenhagen near Stralsund, Pomerania, northern Germany; fig. 2, stereo-pair, specimen GPIMH 2569 (upper end down) ( $\times 60$ ), boulder no. 1 B 10 from Dornbusch, Isle of Hiddensee (Baltic Sea), Pomerania (age: Lower Upper Viruan, Upper Dalby Formation of Sweden, Middle Ordovician; origin: Sweden (Schallreuter, 1970; 1973; p. 65).

Figs. 3, 5. Saccaminopsis? sp. cf. teschenhagensis sp. nov.: fig. 3, specimen GPIMH 2571 ( $\times 130)$, Backsteinkalk erratic boulder no. 14B2; fig. 5, stereo-pair, specimen GPIMH $2572(\times 130)$, boulder no. $14 \mathrm{~B} 2$.

Fig. 4. Saccaminopsis? sp. cf. syltensis? sp. nov.: stereo-pair, specimen GPIMH 2582 (upper end down) ( $\times 240)$, Öjlemyrflint erratic boulder no. Sy 115, Upper Kaolinsand (Lower Pleistocene), near Braderup, Isle of Sylt (North Sea).

Fig. 6. Saccaminopsis? sp. nov. A. Specimen GPIMH $2583(\times 150)$, Öjlemyrflint erratic boulder no. Sy 115. 

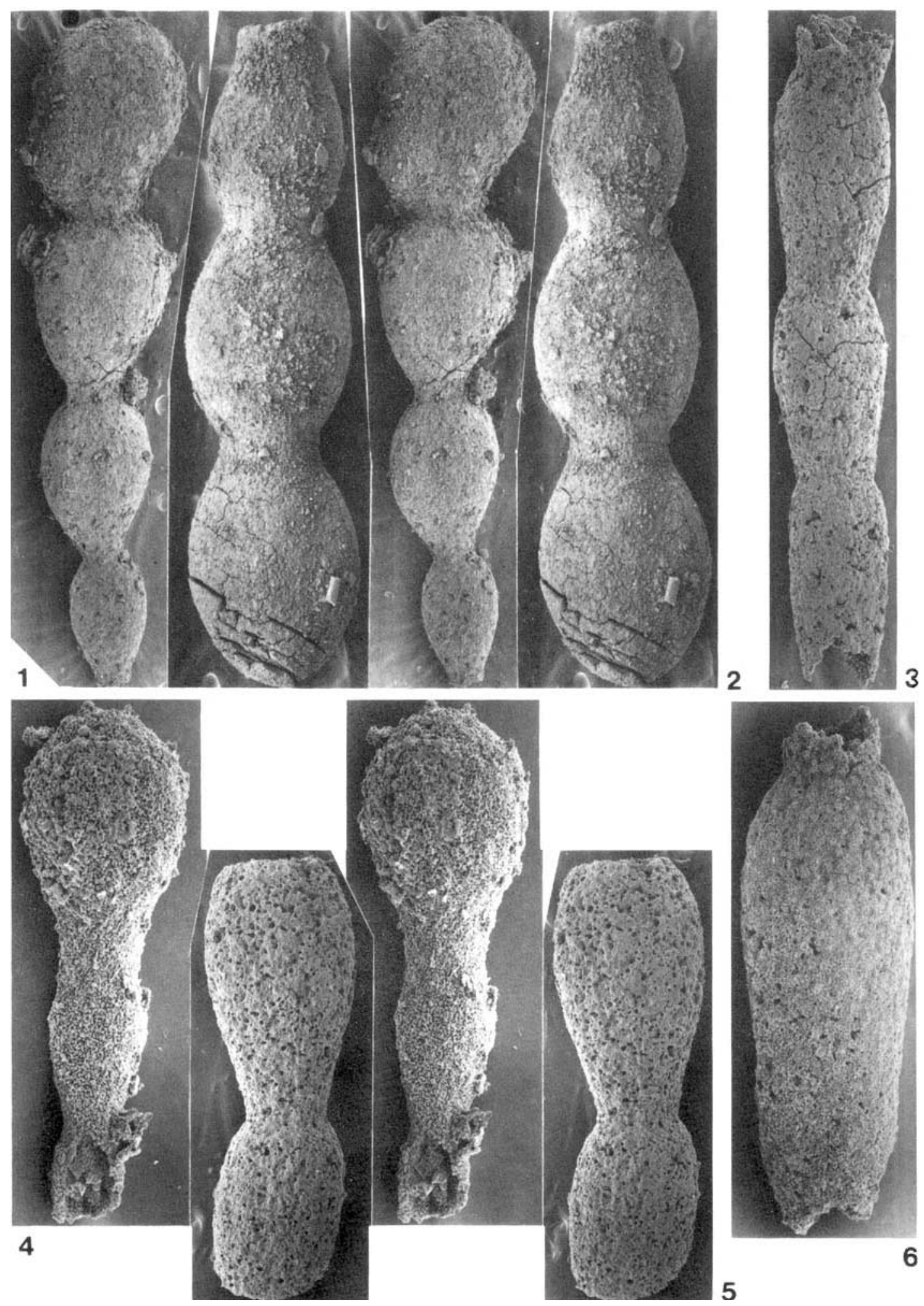


\section{ACKNOWLEDGEMENTS}

I wish to thank Dr. David J. Siveter, University of Leicester, for revising the English manuscript.

\section{REFERENCES}

Brady, H.B. 1871. On Saccammina Carteri, a new Foraminifer from the Carboniferous Limestone of Northumberland. Ann. Mag. Nat. Hist., London, (4) 7 (39), 177-184, pl. 12.

Brady, H.B. 1888. Note on some Silurian Lagenae. Geol. Mag. N. Ser., London, (3) 5 (11), 481-484, pl. 13.

Bykova, E. V. 1956. Foraminifery ordovika i silura Sovetskoj Pribaltiki. Tr. VNIGRI, n. s., Leningrad, 98 (= Mikrofauna SSSR, 8), 6-37, 5 pls., 1 table.

Cummings, R.H. 1952. Saccamminopsis from the Silurian. Proc. Geol. Ass., London, 63 (3), 220-226, 1 fig., 1 table.

Ehrenberg. 1858a. Uber fortschreitende Erkenntniss massenhafter mikroskopischer Lebensformen in den untersten silurischen Thonschichten bei Petersburg. Mber. K. Preuß.) Akad. Wiss. Berlin, 1858 (5), 295-311 (volume for 1859).

Ehrenberg.1858b. Erläuterung der auf Tafel I. abgebildeten untersilurischen Grünsand-Polythalamien. Mber. K. Preu $\beta$ Akad. Wiss. Berlin, 1858 (6), 337, pl. I, (volume for 1859).

Eisenack, A. 1954. Foraminiferen aus dem baltischen Silur. Senckenberg. leth., Frankfurt am Main, 35 (1/2), 51-72, 5 pls., 1 fig.

Eisenack, A. 1971. Die Mikrofauna der Ostseekalke (Ordovizium) 3. Graptolithen, Melanoskleriten, Spongien, Radiolarien, Problematika nebst 2 Nachträgen über Foraminiferen und Phytoplankton. Neues Jb. Miner. Geol. Paläont. Abh., Stuttgart, 137 (3), 337-357, 62 figs.

Loeblich, A.R. \& Tappan, H. 1964. Protista 2 Sarcodina Chiefly "Thecamoebians" and Foraminiferida. In Moore, R.C. (Ed.), Treatise on Invertebrate Paleontology, Pt. C, 1, XXXI + C1 - 510a, figs. 1-399; 2, II + C511-C900, figs. 400-653, Univ. Kansas Press.
Martinsson, A. 1981. Conifers, rotifers and foraminifers. Lethaia, Oslo, 14 (2), 82.

M'Coy, F. 1849. On some new genera and species of Palaeozoic Corals and Foraminifera. Ann. Mag. Nat. Hist., London, (2), 3 (14), 119-136, 5 figs.

Murray, J.W. 1981. Pre-Carboniferous faunas. In Jenkins, D. G. \& Murray, J.W. (Eds.), Stratigraphical Atlas of Fossil Foraminifera, 13-14. Ellis Horwood Ltd., Chichester for the British Micropalaeontological Society.

Schallreuter, R. 1970 Alter und Heimat der Backsteinkalkgeschiebe. Hercynia N.F., Leipzig, 6, [1969] (3), 285-305, 3 figs., 3 tables.

Schallreuter, R. 1973. Tvaerenellidae (Ostracoda, Palaeocopina) aus Backsteinkalk-Geschieben (Mittelordoviz) Norddeutschlands. Palaeontographica (A), Stuttgart. 144 (1/3), 55-111, pls. $16-25,19$ figs., 19 tables.

Schallreuter, R. 1977. Eine neue fragliche kalkschalige Foraminifere aus einem mittelordovizischen Geschiebe Norddeutschlands. Paläont. Z., Stuttgart, 51 (3/4), 227-233, pls. 21-22.

Schallreuter, R. 1979. Ordovizische Problematika, I. Melopetasus gen. n. Paläont. Z., Stuttgart, 53 (1/2), 129-135, 7 figs.

Schallreuter, R. 1980. Ostrakoden aus dem Sularpschiefer (Mittelordoviz) von Schonen (Schweden). Palaeontographica (A), Stuttgart, 169 (1/3), 1-27, 9 pls., 4 figs., 5 tables.

Schallreuter, R. 1980. Ordovizische Problematika, II. Microancienta gen. Paläont. Z., Stuttgart, 54 (3/4), 313-318, 3 figs., 1 table.

Schallreuter, R. 1982. Extraction of ostracods from siliceous rocks. In Bate, R.H., Robinson, E. \& Sheppard, L.M. (Eds.), Fossil and Recent Ostracods, 169-176, 2 pls. Ellis Horwood Ltd., Chichester for the British Micropalaeontological Society.

Sollas, W.J. 1921. On Saccammina carteri BRADY, and the Minute Structure of the Foraminiferal Shell. Q. Jl. geol. Soc. Lond., 77 ( $3=307), 193-212$, pl. 7, 7 figs. 